\title{
Factors Influencing Technology Adoption in Vietnam's Educational System
}

\author{
Nga TRAN ${ }^{1}$, Thanh $\mathrm{LE}^{2}$, Lan NGUYEN ${ }^{3}$, Linh HOANG ${ }^{4}$, Thuy NGUYEN ${ }^{5}$
}

Received: July 18, 2020 Revised: August 23, 2020 Accepted: August 28, 2020

\begin{abstract}
This research aims to shed light on the technology adoption process and its drivers in the Vietnamese educational system. Research data was collected with an online questionnaire from more than 600 teachers in primary schools, secondary schools, high schools, colleges, and universities in Vietnam in 2020. Based on a holistic literature review, we develop a model of two extrinsic factors (global needs and school-infrastructure), and two intrinsic factors (teachers' technological literacy and their beliefs), which are correlated with the teachers' technological adoption. We measure the dependent variable by asking the teachers' ability and their efficacy to implement technology in teaching according to a Likert scale. With the support of SPSS_22 and STATA_2015, we find that over 70\% of changes in technology adoption are explained by the changes in four independent variables and three control variables related to age, gender, and teachinglevel of the teachers. Furthermore, these independent variables are significantly and positively associated with two dependent variables. However, a significant difference in technology integration ability can be seen among teachers' gender, age, and school-level. Specifically, male teachers seem to adopt technology at schools than female teachers better, and university teachers have the lowest level of technology adoption compared to other school-level teachers.
\end{abstract}

Keywords: Teaching Practices, Vietnamese Teachers, Technology Adoption, Technological Ability, Technological Efficacy

JEL Classification Code: M16, M30, M31

\section{Introduction}

It is no exaggeration to say that the Information Communication and Technology (ICT) has brought

${ }^{1}$ First Author. Teacher, Thi Tran High School, Kien Giang, Viet Nam. Email: tranthithanhnga3587@gmail.com

${ }^{2}$ School of Human Resource, Hanoi University of Home Affairs, Vietnam. Email: lethanh.huha@gmail.com

${ }^{3}$ Corresponding Author. School of Accounting and Auditing, Van Lang University, Ho Chi Minh City, Vietnam [Postal Address: 45 Nguyen Khac Nhu Street, Co Giang Ward, District 1, Ho Chi Minh City, 700000, Vietnam] Email: ntnlan@vanlanguni.edu.vn; nguyenthingoclan29071997@gmail.com

${ }^{4}$ Department of Basis Science, Van Lang University, Ho Chi Minh City, Vietnam. Email: linhan274.Ih@gmail.com

${ }^{5}$ Quality Management Division, Department of Education and Training, Hung Yen, Vietnam. Email: thuythptmyhao@gmail.com

(c) Copyright: The Author(s)

This is an Open Access article distributed under the terms of the Creative Commons Attribution Non-Commercial License (https://creativecommons.org/licenses/by-nc/4.0/) which permits unrestricted non-commercial use, distribution, and reproduction in any medium, provided the original work is properly cited. remarkable educational changes, and influenced the advanced social orders since the late twentieth century (Kia, Shayan, \& Ghotb, 2000; Marcinkiewicz, 1996; Byun, 2018). ICT is a unique mechanical system for any organization and country to achieve commercial and instructional development before ensuring competitive advantages because it is progressively imperative in our educational framework (Taylor, 2015; Nguyen \& Luu, 2020). Indeed, it is used as an intelligent communicating device, which is sufficiently sensible to capture the dramatic shifts in the educational environment, to deal with practical issues related to learning and teaching methods (Knezek \& Christensen, 2008; Muneer, 2020). Consequently, the necessity of ICT adoption in teaching has been arising due to the high demand for aptitude and knowledge of students in the era of universal integration. According to Knezek and Christensen (2008), in the fourth industrial revolution, teachers need to equip themselves with essential skills and practical knowledge about ICT implementation to enhance further their teaching techniques as well as the students' absorption process. This, therefore, raises the question of what is the nature of ICT and its determinants? 
Over time, many researchers and practitioners have paid attention to ICT adoption; however, its definition is still a topic of discussion. Generally, they define the adoption of technology in various perspectives, which are associated with either educational technology or individual decision of innovation exercise (Ertmer, 1999). They argue that technology adoption describes the process of "acceptance, integration, and use of new technology" in teaching and learning methods (Levin \& Wadmany, 2006). This process comprises a set of different steps, which are influenced by two knock-on effects. The first effect is released by external constraints, called first-order barriers, consisting of "hardware and Internet access, software and tool access, training, and support" (Ertmer, Ottenbreit-Leftwich, Sadik, \& Sendurur, 2012). The second effect is related to internal factors ranging from teachers' beliefs and attitudes towards the incorporation of educational technology to their instructive preparations. Indeed, both types of factors are said to have significant impacts on educational changes, so, provided that those factors are profoundly addressed, the extent of the success of technology integration could be improved.

However, the rates of technology integration in impoverished countries are as slow as molasses due to the complexity of ICT in a working environment. Consequently, most researchers and educators have raised concerns about how to gain a degree of technology integration in the classrooms successfully. Compared with developed countries where technology is widely used, developing countries seem to be left behind in the race of technological development. Indeed, empirical evidence points to the fact that the wellequipped technological infrastructure and human capital support are two main reasons that are responsible for the backwardness of education in developing countries (Zhao, Pugh, Sheldon, \& Byers, 2002; Levin \& Wadmany, 2006). Aldunate and Nuss (2013) suggest that the national investment on equipment and necessary, updated software are essential stages for schools to maintain an effective teaching environment. In turn, this would allow teachers and students to improve their integrated hands-on lessons via various forms of advancement. Therefore, it can be said that unless developing countries' educational environments are good enough, teachers from these countries are not bound to be confident to utilize technical tools soon.

Nonetheless, it also is argued that, although the extension of available technical facilities is addressed, this could not necessarily improve the quality of teaching and learning practice (Cuban, 1986). Besides, teachers find it arduous to apply technological applications because of their insufficient skills, experiences, or even lack of basic computer skills. These problems result in the absence of incorporating technological devices into their daily lessons. Gustafson (1978) claims that a lot of teachers are not sensible enough to catch up with the changes in technology as well as automation in education. In preparation for fighting for the rational improvement of national education, underdeveloped nations have invested a considerable amount on education to build up the teachers' ability in technology adoption. This human resource will be devoting time and effort to educational development and stable socio-economic growth. Precisely, in 2013, around 16,5\% of governments' total budget in East Asia and Pacific countries went into education, while the figure for Vietnam's educational expenditure reached $18.5 \%$, higher than the global average of 14.1\% (UNESCO, 2017). It shows how much the Vietnamese Government's attention has been paid to education.

Several studies, however, point out that the technical training process plays an important role in teachers' successful adoption. This is because different relevant technical training courses such as the educational software amendment can further supply teachers with essential skills to enhance their technical knowledge before improving their teaching performance (Zhao, Pugh, Sheldon, \& Byers, 2002). Teachers' priority adoption of technology integration also depends on catering services, namely, the available hardware, software, and time for teachers' preparations (Bingimlas, 2009; Mumtaz, 2000; Ertmer, 1999). This is because, without an IT service support, teachers are unable to solve some related technical issues timely, so their access to technological advancement, therefore, is hidden. Furthermore, school infrastructure, which includes laboratory, library, and classroom, is another important driver relating to the technology adoption at schools (Wastiau, Blamire, Kearney, \& Quittre, 2013). Then again, the more teachers may get access to infrastructure and resources, the more they will frequently be able to update their innovation capabilities.

In summary, although there is much empirical evidence related to the importance of teachers' technology adoption and its determinants in developed countries, few studies are undertaken in developing countries (Jhurree, 2005). This result is the shortage of literature focusing on developing countries in which the technology, environment, and economy are significantly different from those in developed countries. It would be inappropriate for the Vietnamese educational system to apply the theoretical concept and empirical models of developed countries in analyzing the technology adoption at school. Thus, in this paper, we will measure the teachers' technology adoption by their efficacy and ability as two dependent variables, then evaluate the impact of global needs, school infrastructure, technological literacy, and beliefs on these dependent variables. This study aims to carry out a broader empirical examination, utilizing qualitative methods to evaluate the teachers' priority in technology integration in Vietnam and clarify its main independent variables. The data of this research were collected via questionnaires from 
Nga TRAN, Thanh LE, Lan NGUYEN, Linh HOANG, Thuy NGUYEN /

various subject teachers at schools in Vietnam to ensure representativeness, completeness, and reliability.

\section{Literature Review}

Currently, technology integration overwhelming every field of life has become an enthralling topic that appeals to educational researchers (Jhurree, 2005; Mikre, 2011). Aiming to revolutionize education, governments in several countries have taken some measures to implement ICT in their educational systems (Kozma \& Vota, 2014). They expect that teachers can adapt the technology as a beneficial apparatus to augment the educational curriculum efficiently. Gaining teachers' insight into adopting innovation, therefore, will gradually turn conventional methods or traditional teacher-centered methods into student-centered approaches (Windschitl \& Sahl, 2002). Accordingly, recent innovation has the potential to bolster the instruction over the curriculum and the compelling communication (that had not existed before) between teachers and students (Bingimlas, 2009). Conceptions related to technology adoption were both formed and grouped into different clusters of minds. The first one is aligned with educational technology. However, unlike earlier studies, some definitions of innovation are individual decisions made by teachers to take up technology (Rangaswamy, Arvind; Gupta, Sunil (2000). Another one is synonymous with the choice of a person to form the use of an innovation as the best course of activity accessible (Rogers, 1995). Thus, personal adoption is imperative and influences the process of instructors' innovation incorporation.

Various empirical studies examining the variables of teachers' technology adoption are categorized into different elements involving teachers' innovation adoption divided into two predominant groups: (1) external factors: national infrastructure, time, global need; (2) internal agents: personal belief, attitude, self-ability, and self-efficacy. In terms of external indicators, there is a high likelihood that teachers' technology adoption has a close relationship with infrastructure and global needs, which will thrust teachers into consistent practices. School facilities are indispensable for teachers' determination to select technology since providing teacher-based structures and adequate time (Fullan, 2000) is the first required step preparing teachers to incorporate technology successfully to meet society's needs. If teachers stimulate students' learning activities through software devices to get the learners' attraction on purpose and cultivate an interpersonal relationship, learners' academic performances of using technological skills will gradually be improved since students will stand a good chance of imitating teachers' technology practice as their regular habits. Hence, when teachers are equipped with the technical availability and accessibility, this will results in tremendous outcomes, holding over the educational system in the future.
Internal factors are divided into various aspects: teachers' beliefs, their abilities, their attitude, and their motivations (Ertmer, 1999; Chen, 2014; Ertmer, OttenbreitLeftwich, Sadik, \& Sendurur, 2012), and their technical efficacy (Bandura, 1994; Tschannen-Moran \& Johnson, 2010). Accordingly, self-ability exemplifies human ability, "acquirable skills," while self-efficacy illustrates how people perceive, deem, and stimulate themselves (Bandura, 1993). In other words, self-ability is regarded as teachers' capability of using innovation, one of the most appropriate standards for evaluating teachers' technology integration. Self-efficacy determinants rely on human motivation with the core beliefs, leading to the direct influential factor of teachers' innovation adoption. It is believed that teachers with a high level of technical ability and efficacy could control and have a strong impact on students' accomplishments and enthusiasm (Tschannen-Moran, Hoy, \& Hoy, 1998). Besides, taking advantage of technology in teaching is the most effective way to increase teaching efficiency before enhancing educational processes (Bandura, 1994). In this research, therefore, we will examine the efficacy and ability of teachers to use technology in the classroom based on the cognitive theory of Bandura (1994, 2009). This is because self-ability and self-efficacy are interrelated to the teacher perception process; consequently, they determine the technological implementation of teachers in the classroom.

In Vietnam, very few researchers did investigate the determinants of technology adoption in teaching practices. This leads educators and educational plan makers to face many difficulties in revolutionizing the education reform. According to Nguyen and Nguyen (2008), the Vietnamese Government has conducted many educational reforms, from primary school to higher education such as staff qualifications, new curriculums and textbook production, educational makers, and human resources in the $21 \mathrm{st}$ century. However, they did not take teachers' pre-service technology training as well as pre-service teachers' ICT ability and efficacy into account; therefore, the educational dilemmas remain unchanged. This is because most research findings are conducted in developed countries that have a considerable gap comparing to developing countries, particularly in Vietnam. Therefore, not only does this research aim to confront the issues unlike earlier research, but it also evaluates the determinants of teachers' technology adoption in different schools in Vietnam.

\section{Hypothesis and Research Methodology}

\subsection{Hypothesis}

To assess and evaluate the experimental factors on teachers' priority adoption of integrating technology, the paper focuses on building four research hypotheses below, 
corresponding to four independent variables: global needs, national infrastructure, teacher literacy, and teacher beliefs in sequence.

H1: Global needs are positively correlated with teachers' priority adoption of integrating technology

Albirini (2006) and Jimoyiannis and Komis (2006) point out that the adoption of technology into the educational realm has become a global issue, which is a topic of discussion among many researchers and practitioners. This is because taking advantage of technology in education not only helps to transform the superannuated education system, but also encourage students to generate better outcomes. In response to improving and enhancing Vietnam's shift to the market economy, educational planners have had to bear in mind strategies for making instructive framework responsive to current and future workforce demand (Duggan, 2001). As a result, in Central Resolution II Session VIII, the Communist Party of Vietnam (1996) determines the strategic direction for the improvement of science and technology and even states that "Innovating methods of education and training imparted to overcome one-sided manner, the routine practice creative thinking of students." Therefore, teachers could adapt to the technology attainment and apply it in the provision of compulsively electronic lessons to espouse students' collaboration.

H2: National infrastructures have a positive association with teachers' priority adoption of technology integration.

In the light of Charles Buabeng-Andoh (2012), the infrastructure and resources comprising of hardware television, motion pictures, audiotapes and discs, textbooks, blackboards, and so on (Engler, 1970) are necessary conditions. They, indeed, have tremendous impacts on teachers' priority of technology adoption in the classroom. The teachers themselves can improve their ability to integrate technology at school if and only if they are fully offered technical availability and accessibility. Otherwise, teachers will not have an opportunity to utilize technological services in case they do not get access to technological tools. This would mean that the improvement in teaching infrastructure enables teachers to further develop and enhance their IT skills before amending new technological supports in improving teaching quality. Thereby, it can be said that teachers' adoption of technological innovation depends on the available and accessible resources such as software, hardware as well as updated application.

H3: Teacher literacy has a positive impact on teachers' priority adoption of technology integration.
Technology literacy is defined as "the individuals' abilities to adopt, adapt, invent, and evaluate technology to positively affect his or her life, community, and environment" (Hansen, 2000). Another definition of innovatively proficient individuals can use innovation as a device for "organization, communication, research and problem-solving" (Eisenberg \& Johnson, 2002). Undeniably, developing teacher literacy of the technology realm is of great significance because teachers are thought at the center of the academic reform efforts, both as active contributors and as leaders of students' activities. Jimoyiannis and Komis (2006) assert that the understanding of the ICT effect on teachers is consequently crucial. Accordingly, teachers' technological literacy, which can revolutionize the nature of classroom technology integration, attributes great efforts of enhancing the high educational standard in general and students' technological skills.

H4: Teachers' beliefs are positively related to teachers' priority adoption of technology integration.

Teachers' pedagogical beliefs are listed as intrinsic factors related to academic convictions and beliefs of how innovation can encourage the methods of putting pedagogical convictions into hones (Chen, 2014). Many empirical pieces of evidence illustrate that these factors are significantly associated with both academic decisions and classroom practices of teachers (Pajares, 1992). Indeed, teachers are active educators affecting students' attitudes when conducting computers for instructional purposes. Besides, Bandura (2010) adds teacher's beliefs as a fundamental element that motivates and enhances environmental learning, then influences the achievement of students' academic performances. This is because, without strong beliefs of being capable of using technology, teachers can not only collaborate but also facilitate students in the classroom efficiently. This results negatively on the teacher's willingness to change, a positive indicator determining the integration of technology into the classroom (Aldunate \& Nussbaum, 2013; Mueller, Wood, Wiloughby, Ross, $\&$ Specht, 2008). There is little doubt to say that teachers' beliefs are of great importance to the process of technology adoption, especially in daily educational practices.

\subsection{Empirical Models}

In this research, the authors apply both SPSS 22 and STATA 2015 to consider five different variables on teachers' priority adoption. These independent variables are teachers' technology adoption, global needs, national infrastructure, teacher literacy, and teacher beliefs. Since then, we also apply both qualitative methods within theoretical reviews and quantitative research into correlation and regression models. 
Nga TRAN, Thanh LE, Lan NGUYEN, Linh HOANG, Thuy NGUYEN /

To measure the impact of age, gender, school position on technology adoption among teachers, we add further these demographics indicators as control variables. Two different models, following two different dependent variables, are built as the following:

$$
\begin{aligned}
\text { Model 1: } \mathrm{ADO} 1= & \alpha+\beta 1 * \mathrm{GNE}+\beta 2 * \mathrm{INF}+\beta 3 * \mathrm{TEC} \\
& +\beta 4 * \mathrm{BEL}+\beta 5 \mathrm{AGE}+\beta 6 \mathrm{GENDER} \\
& +\beta 7 \mathrm{SCHOOL}+\varepsilon \\
\text { Model 1: } \mathrm{ADO} 2= & \alpha+\beta 1 * \mathrm{GNE}+\beta 2 * \mathrm{INF}+\beta 3 * \mathrm{TEC} \\
& +\beta 4 * \mathrm{BEL}+\beta 5 \mathrm{AGE}+\beta 6 \mathrm{GENDER} \\
& +\beta 7 \mathrm{SCHOOL}+\varepsilon
\end{aligned}
$$

Where: $\alpha, \beta 1, \beta 2, \beta 3, \beta 4, \beta 5, \beta 6$, and $\beta 7$ are coefficients, and $\varepsilon$ is an error.

Different variables having its meaning and function are as follow:

\subsection{Research Method}

\subsubsection{Selection of the Research Objects and Scopes}

We have selected some different schools with different levels, including (1) primary schools, (2) secondary schools, (4) high schools, (4) colleges, and (5) universities in the South of Vietnam. At these schools, teachers have focused on learning how to implement technology in the teaching practice and have encountered numerous problems in the ICT amendment to accelerate the frequency of computer usage. We proceeded to select randomly and conduct interviews with some secondary teachers and college and university lecturers to broaden our understanding. The selected teachers are from different schools, colleges, and universities.

\subsubsection{Data Collection and Analyzing Process}

We conducted a questionnaire, which is about age, gender, school position, and information technology ability of teachers. Next, through the permission of the principals of these schools, we joined a monthly meeting at some selected schools to collect teachers' responses. After collecting data from face-to-face interviews and questionnaires, we entered data into Microsoft Excels. We calculated the teachers' responses based on a Likert scale with a grades score of 1-5. After this step, the remaining observations for each level of schools are presented in Table 2.

Table 2 shows that most participants are from high schools and senior school. The number of teachers from

\begin{tabular}{|c|c|c|c|c|}
\hline Variable & Meaning & Determined by & Role & Model \\
\hline \multirow{2}{*}{ ADO } & \multirow{2}{*}{$\begin{array}{l}\text { Teachers' technology } \\
\text { adoption }\end{array}$} & Self- ability & Dependent variable & ADO1 \\
\hline & & Self-efficacy & Dependent variable & ADO2 \\
\hline \multirow{4}{*}{ GNE } & \multirow{4}{*}{ Global needs } & Demand for highly qualified teachers & Independent variable & GNE1 \\
\hline & & Teachers' technology recognition & Independent variable & GNE2 \\
\hline & & Communication technology developments & Independent variable & GNE3 \\
\hline & & Social obligation & Independent variable & GNE4 \\
\hline \multirow{3}{*}{ INF } & \multirow{3}{*}{ Infrastructure } & Catering services & Independent variable & INF1 \\
\hline & & Labs and classrooms & Independent variable & INF2 \\
\hline & & Software/ hardware & Independent variable & INF3 \\
\hline \multirow{4}{*}{ TEC } & \multirow{4}{*}{ Teacher Literacy } & Experience and skills & Independent variable & TEC1 \\
\hline & & Technical training for teachers. & Independent variable & TEC2 \\
\hline & & Teachers' upgrades & Independent variable & TEC3 \\
\hline & & Technology integration & Independent variable & TEC4 \\
\hline \multirow{4}{*}{ BEL } & \multirow{4}{*}{ Teachers' believes } & Personal accessibility & Independent variable & BEL1 \\
\hline & & Unexpected technical obstacles & Independent variable & BEL2 \\
\hline & & Changing willingness & Independent variable & BEL3 \\
\hline & & Personal motivation & Independent variable & BEL4 \\
\hline
\end{tabular}
university and college only accounts for $18 \%$ of the total observations. Out of a total of 602 respondents, we have 76 teachers from primary schools, which makes up $13 \%$ of the research samples.

Table 1: List of dependents and independent variables of the regression models. 
Table 2: Research samples

\begin{tabular}{|l|c|c|c|c|c|c|}
\hline Schools/Age & $\mathbf{2 1 - 2 9}$ & $\mathbf{3 0 - 4 0}$ & $\mathbf{4 1 - 5 0}$ & $\mathbf{5 0 - 6 0}$ & Total & $\mathbf{3}$ \\
\hline College & 12 & 0 & 24 & 0 & 36 & 72 \\
\hline University & 12 & 36 & 24 & 0 & $12 \%$ \\
\hline Junior high school & 38 & 114 & 62 & 16 & 230 & $38 \%$ \\
\hline Senior high school & 18 & 78 & 52 & 40 & 188 & $31 \%$ \\
\hline Primary school & 18 & 48 & 10 & 0 & 76 & $13 \%$ \\
\hline Total & 98 & 276 & 172 & 56 & 602 & $100 \%$ \\
\hline$\%$ & $16 \%$ & $46 \%$ & $29 \%$ & $9 \%$ & $100 \%$ & \\
\hline
\end{tabular}

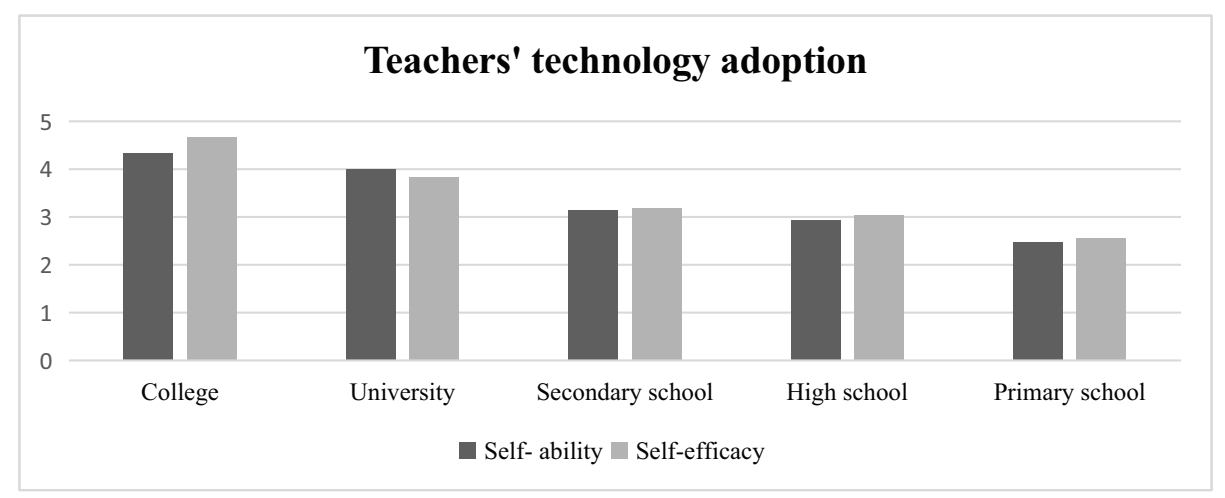

Figure 1: Teacher's technology adoption

\section{Results}

\subsection{Descriptive Analysis}

From the data gathered, Figure 1 illustrates two composite indicators, including ADO1 (self-ability), ADO2 (self-efficacy) from the five types of schools (colleges, universities, junior high schools, senior high schools, and primary schools). As can be seen from the chart, generally, teachers at colleges have the highest levels of self-ability and self-efficacy among those schools, with a figure reaching 4,33 and 4,66, respectively. By contrast, teachers at primary schools are on a reverse pattern with the lowest levels of self-ability and self-efficacy to about 2.5. Similarly, the university experienced the second largest number of teachers' self-ability, and self-efficacy (at about 4 and 3.83, respectively), those of secondary schools came third, high schools came next. To put it another way, college teachers rate their self-efficacy two-fold comparing to teachers at elementary schools. In contrast, secondary and high school teachers' self-ability and self- efficacy are nearly the same with about 3.13, 3.18, 2.93, and 3.03 in the order given.

Figure 2 illustrates the comparison of the technology infrastructure teacher's rank in five different types of schools. Overall, there was the greatest number of software/ hardware, labs, and classrooms, and catering services at colleges, accounting for 4.0, showing a higher figure than the other schools. At the same time, the lowest technology infrastructure belonged to elementary schools with the numbers at 2.21, 2.92, 2.21, respectively, in comparison with that of senior high schools, secondary schools, and universities. In terms of labs and classrooms, they were the highest between the other two categories of schools (primary schools, high schools, and elementary schools), accounting for $2.92,3.11,2.99$, in that order. Similarly, software/ hardware showed the same trend. In contrast, a low number of the provision of software/hardware and catering service for primary teachers were just above 2 .

\subsection{Regression Analysis}

\subsubsection{Measuring Reliability}

For STA variables, the test results depict that the observed STA variables have an appropriate total correlation coefficient $(\geq 0.3)$. Cronbach's alpha coefficient $=0.84$ $\geq 0.8$, so the variables GNE1, GNE2, GNE3, and GNE4 meet the requirements of reliability and are very good measurement scales representing the variable GNE. As for INF, the test results of the observed INF variables indicate an 
Nga TRAN, Thanh LE, Lan NGUYEN, Linh HOANG, Thuy NGUYEN /

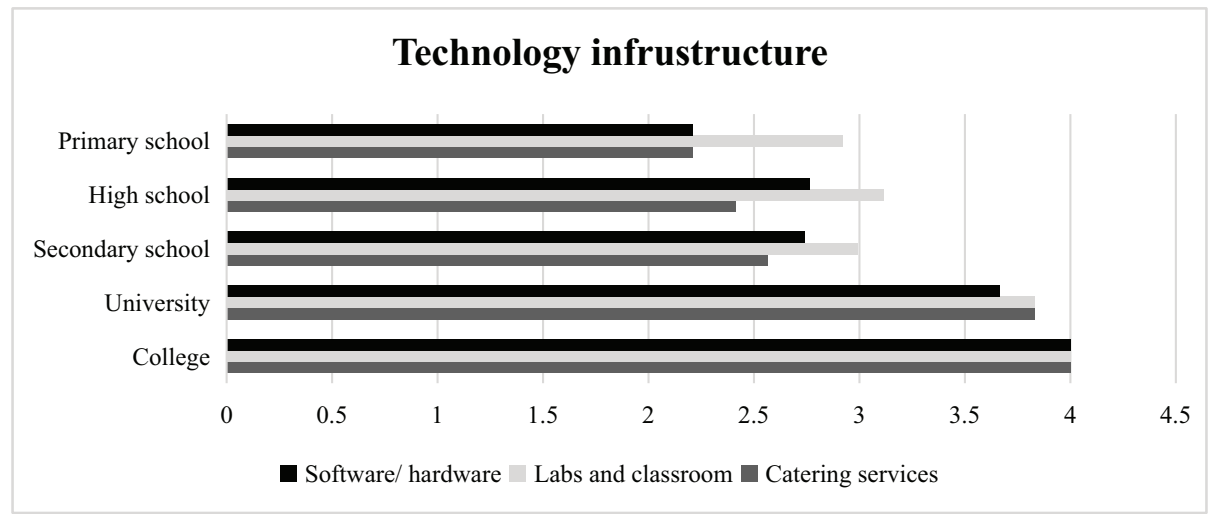

Figure 2: Technology Infrastructure at Schools

appropriate total correlation coefficient $(\geq 0.3)$. Cronbach's alpha coefficient $=0.89 \geq 0.8$, so the variables INF1, INF2, and INF3 meet the requirements of reliability and are very good measurement scales representing the variable INF. Speaking of TEC variables, the test results of the observed TEC variables show an appropriate total correlation coefficient $(\geq 0.3)$. Cronbach's alpha coefficient $=0.92 \geq$ 0.9 , so the variables TEC1, TEC2, TEC3, and TEC4 meet the requirements of reliability and are very good measurement scales representing the variable TEC. When it comes to TEC variables, the test results indicate the observed BEL variables have an appropriate total correlation coefficient $(\geq 0.3)$. Cronbach's alpha coefficient $=0.647 \geq 0.6$; thus, the variables BEL1, BEL3, and BEL4 meet the requirements of reliability and are very good measurement scales representing the variable BEL. However, the Cronbach's alpha of variable BEL2 $=-0,047<0.6$ does not meet the requirement of the reliability; hence, we eliminate this variable to make sure that the others are exactly estimated.

\subsubsection{Analysis of EFA}

The analysis of the EFA discovering factors shows that, as $0.5<\mathrm{KMO}$ coefficient $=0.909<1,000$, the analysis of the factor is consistent with the research data set. Also, Bartlett's test of sphericity has shown that the observed variables in the same factor are correlated with each other owing to Sig (Bartlett's test) $=0<0.05$. From the analysis of the independent variables embraced in the model, we find that three factors are extracted at Eigenvalue: 1.131. The Eigenvalue is $0.832<1$ if the model using more factors (the fourth factor). Thus, we stop at the third factor to assure if we depend on Eigenvalues criteria one or more. Furthermore, since total variance explained $=74.686 \%>50 \%$ shows the EFA model is satisfactory. Hence, the three extracted factors will explain $74.686 \%$ of the variability of the observation.
As per the rotated matrix results, variables GNE3, BEL3 will be excluded from the model due to the following reasons:

-The variable BEL3 upload in both component 1 and component 2 that lead to violating the discrimination in the rotation matrix with the difference in a load factor of less than 0.3

-The variable GNE3 uploads in component 1, 2, and 3, violating the discriminatory nature in the rotation matrix with the difference of the load coefficient less than 0.3

After making the reliable measurement of the independent variables using Cronbach's alpha test and EFA discovery factor analysis, the remaining variables in the models sorted are as follow.

Unlike the hypothetical model, independent variables were formed into three new groups TEC, GNE, and INF instead of four clusters as given. While, along with TEC1, TEC2, TEC3, TEC4, TEC variables included BEL1 and BEL4 after data processed since BEL1 and BEL4 are closely related to TEC. After getting rid of GNE4, GNE variables got three variables (GNE1, GNE2, GNE3). Specifically, INF variables remain the same.

\subsubsection{Correlation Analysis}

We test the correlation among the variables through SPSS's results in five different schools involving primary schools, secondary schools, high schools, colleges, and universities in Vietnam in 2020. What stands out from the test is that all dependent determinants and independent variables closely correlate to each other, and independent variables are the same patterns. Therefore, the multicollinear phenomenon among these variables would not be likely to arise. Moreover, the table shows that there are linear relationships recorded among groups: ADO1, ADO2, TEC, GNE, and INF, so that is to say, ADO1 and ADO2 impacts positively on TEC, GNE, and INF and all independent variables impacts positively on ADO1 and ADO2. 
Table 3: Total Variance Explained

\begin{tabular}{|c|c|c|c|c|c|c|c|c|c|}
\hline \multirow{2}{*}{ No. } & \multicolumn{3}{|c|}{ Initial Eigenvalues } & \multicolumn{3}{|c|}{$\begin{array}{l}\text { Extraction Sums of Squared } \\
\text { Loadings }\end{array}$} & \multicolumn{3}{|c|}{$\begin{array}{c}\text { Rotation Sums of Squared } \\
\text { Loadings }\end{array}$} \\
\hline & Total & $\begin{array}{c}\% \text { of } \\
\text { Variance }\end{array}$ & Cumulative \% & Total & $\begin{array}{c}\% \text { of } \\
\text { Variance }\end{array}$ & Cumulative \% & Total & $\begin{array}{c}\% \text { of } \\
\text { Variance }\end{array}$ & $\begin{array}{c}\text { Cumulative } \\
\%\end{array}$ \\
\hline 1 & 7.98 & 57.02 & 57.025 & 7.98 & 57.025 & 57.025 & 4.71 & 33.701 & 33.701 \\
\hline 2 & 1.34 & 9.582 & 66.607 & 1.34 & 9.582 & 66.607 & 2.90 & 20.720 & 54.421 \\
\hline 3 & 1.13 & 8.079 & 74.686 & 1.13 & 8.079 & 74.686 & 2.83 & 20.265 & 74.686 \\
\hline 4 & .815 & 5.823 & 80.508 & & & & & & \\
\hline 5 & .546 & 3.898 & 84.406 & & & & & & \\
\hline 6 & .406 & 2.903 & 87.309 & & & & & & \\
\hline 7 & .346 & 2.472 & 89.780 & & & & & & \\
\hline 8 & .298 & 2.131 & 91.911 & & & & & & \\
\hline 9 & .288 & 2.056 & 93.967 & & & & & & \\
\hline 10 & .221 & 1.581 & 95.548 & & & & & & \\
\hline 11 & .190 & 1.359 & 96.907 & & & & & & \\
\hline 12 & .172 & 1.226 & 98.133 & & & & & & \\
\hline 13 & .135 & .963 & 99.096 & & & & & & \\
\hline 14 & .127 & .904 & 100.000 & & & & & & \\
\hline
\end{tabular}

\subsubsection{Regression Analysis}

Table 4 shows regression results for self-ability (ADO1) and self-efficacy models (ADO2) with and without demographic factors. The differences arise if demographic factors are included in two models. However, demographic factors only account for $1.1 \%$ and $3.2 \%$ of the changes in $\mathrm{ADO} 1$ and ADO2, respectively. Overall, based on the $\mathrm{R}$-square results, it can be said that the technology adoption by teachers is explained by over $70 \%$ of the changes in teaching literacy, global needs, infrastructure, and demographic factors. These results confirm the significant impact of intrinsic, extrinsic, and demographic drivers on technology implementation in teaching.

In the ADO1 model, because R-squared equal to 0.753 , it can be said that the change in ADO1 is explained by $75.3 \%$ of the variation of three independent variables and demographic variables. Specifically, a significant positivity can be seen in the correlation off TEC and GNE with ADO1, indicating that these variables have a significantly positive impact on ADO1 with statistical significance at $99 \%$. By contrast, a negative relationship is shown between primary schools and ADO1, indicating that teachers from primary schools have a lower level of technical ability than those from other schools. The other variables, including INF, AGE, GENDER, secondary school, high school, and university, have a statistically insignificant association with the ADO1.

Regarding model $2 \mathrm{~b}$, because the R-squared equals to 0.706 , it can be said that the change in $\mathrm{ADO} 2$ is explained by $70.6 \%$ of the variation of all independent variables. In different phrases, independent variables play a tremendous role, greatly influencing the dependent variable. With the statistical significance of $95 \%$, while TEC, GNE, and INF, have a significant positive correlation with ADO2, the remaining variables, including GENDER, AGE, and SCHOOL are negatively associated with ADO2. This means that an increase in teaching literacy, global needs, and infrastructure would lead to an increase in technology adoption efficacy. At the same time, a reverse pattern can be seen in the relationship between demographic factors and the $\mathrm{ADO} 2$.

Interestingly, because of the negative coefficient found in GENDER, male teachers seem to have a higher level of self-efficacy in implementing technology in teaching than female teachers. Moreover, significant differences in selfefficacy between teachers from different schools can be seen in the model $2 \mathrm{~b}$. Specifically, all coefficients in primary school, secondary school, high school, and university are significantly negative, indicating that teachers from colleges have the highest level of self-efficacy compared to those from other school types. 
Nga TRAN, Thanh LE, Lan NGUYEN, Linh HOANG, Thuy NGUYEN /

Table 4: Empirical models

\begin{tabular}{|c|c|c|c|c|}
\hline & (1a) & (1b) & (2a) & (2b) \\
\hline VARIABLES & ADO1 & ADO1 & ADO2 & ADO2 \\
\hline \multirow[t]{2}{*}{ TEC } & $0.843^{* * *}$ & $0.820^{* * *}$ & $0.712^{* * *}$ & $0.711^{* * *}$ \\
\hline & $(0.0318)$ & $(0.0337)$ & $(0.0367)$ & $(0.0378)$ \\
\hline \multirow[t]{2}{*}{ GNE } & $0.105^{\star * *}$ & $0.125^{\star \star \star}$ & $0.214^{* * *}$ & $0.234^{* * *}$ \\
\hline & $(0.0326)$ & $(0.0331)$ & $(0.0376)$ & $(0.0371)$ \\
\hline \multirow[t]{2}{*}{ INF } & 0.0394 & 0.0394 & $0.101^{* * *}$ & $0.100^{* * *}$ \\
\hline & $(0.0287)$ & $(0.0284)$ & $(0.0332)$ & $(0.0319)$ \\
\hline \multirow[t]{2}{*}{ GENDER } & 0.0371 & 0.0458 & $-0.104^{\star *}$ & $-0.196^{* * *}$ \\
\hline & $(0.0448)$ & $(0.0464)$ & $(0.0518)$ & $(0.0520)$ \\
\hline \multirow[t]{2}{*}{ AGE } & 0.00946 & 0.00522 & 0.0467 & $0.0545^{*}$ \\
\hline & $(0.0256)$ & $(0.0262)$ & $(0.0295)$ & $(0.0294)$ \\
\hline \multirow[t]{2}{*}{ Primary school } & & $-0.220^{\star *}$ & & $-0.523^{* * *}$ \\
\hline & & $(0.107)$ & & $(0.120)$ \\
\hline \multirow[t]{2}{*}{ Secondary school } & & 0.0788 & & $-0.262^{* *}$ \\
\hline & & $(0.0928)$ & & $(0.104)$ \\
\hline \multirow[t]{2}{*}{ High School } & & -0.0824 & & $-0.386^{\star * *}$ \\
\hline & & $(0.0933)$ & & $(0.105)$ \\
\hline \multirow[t]{2}{*}{ University } & & -0.0672 & & $-0.716^{\star * *}$ \\
\hline & & $(0.0983)$ & & $(0.110)$ \\
\hline \multirow[t]{2}{*}{ Constant } & -0.0138 & 0.0120 & -0.221 & 0.0832 \\
\hline & $(0.132)$ & $(0.192)$ & $(0.152)$ & $(0.215)$ \\
\hline Observations & 602 & 602 & 602 & 602 \\
\hline R-squared & 0.741 & 0.753 & 0.674 & 0.706 \\
\hline
\end{tabular}

Standard errors in parentheses ${ }^{* * *} p<0.01,{ }^{* *} p<0.05,{ }^{*} p<0.1$

\section{Conclusions}

This study was conducted to evaluate the ability and efficacy of teachers in adopting technology in teaching activities at primary schools, secondary schools, high schools, and universities. After conducting interviews and surveys with more than 600 teachers in the South of Vietnam, the research results emphasize that technology implementation is explained mainly by teacher literacy, global needs, and school infrastructure. These variables have a significant positive impact on the self-ability and self-efficacy of teachers in adopting the technology. Besides, the relationship between demographics and technology adoption was tested and indicated that male teachers have a stronger efficacy in implementing technology than female teachers. The result of the study also shows the impact of age and school positions on the teachers' technological efficacy. It points out that younger teachers seem to have a lower level of teaching experience, therefore, having a lower level of technological efficacy than experienced teachers. The correlation between school types and technology implementation is significant. The results show that teachers from colleges seem to have higher efficacy levels in adopting technology than those from other schools. In conclusion, this research has examined attributions on technological implementation in teaching activities, which are useful for school administrators to recognize the ability and the effectiveness of teachers in using advanced technology in the classrooms. This research aims to shed light on the importance of teacher literacy, school infrastructure, global needs, and other demographics in influencing the technology adoption in the Vietnamese educational system. 


\section{References}

Albirini, A. (2006). Teachers attitudes toward information and communication technologies: the case of Syrian EFL teachers. Computers \& Education, 47(4), 373-398.

Aldunate, R., \& Nussbaum, M. (2013). Teacher adoption of technology. Computers in Human Behavior, 29(3), 519-524.

Bandura, A. (1993). Perceived Self-Efficacy in Cognitive Development and Functioning. Educational Psychologist, 28(2), 117-148.

Bandura, A. (1994). Self-Efficacy. Encyclopedia of Human Behavior, 4, 71-81.

Bandura, A. (2009). Cultivate Self-efficacy for Personal and Organizational Effectiveness. In: Handbook of Principles of Organization Behavior (pp. 179-200). New York, NY: Wiley. Retrieved from https://www.uky.edu/ eushe2/Bandura/ Bandura2009Locke.pdf

Bandura, A. (2010). Self-efficacy. In: The Corsini Encyclopedia of Psychology (pp. 1-3). New York, NY: Wiley.

Bingimlas, K. (2009). Barriers to the Successful Integration of ICT in Teaching and Learning Environments: A Review of the Literature. Eurasia Journal of Mathematics, Science and Technology Education, 5(3), 235-241.

Buabeng-Andoh, C. (2012). Factors influencing teachers' adoption and integration of information and communication technology into teaching: A review of the literature. International Journal of Education and Development using Information and Communication Technology, 8(1), 136-149.

Byun, S. (2018). Evaluating Information Technology Systems Using Consumer Surveys: The Role of Personal Product Knowledge. Journal of Asian Finance, Economics and Business, 5(4), 117125. http://doi.org/10.13106/jafeb.2018.vol5.no4.117

Chen, C.-H. (2014). Why Do Teachers Not Practice What They Believe Regarding Technology Integration? The Journal of Educational Research, 102(1), 65-75.

Cuban, L. (1986). Teacher and Machines: The classroom use of technology since 1920. New York, NY: Teacher College Press.

Duggan, S. (2001). Educational Reform in Viet Nam: a process of change or continuity? Comparative Education, 37(2), 193-212.

Eisenberg, M. B., \& Johnson, D. (2002). Learning and Teaching Information Technology--Computer Skills in Context. ERIC Digest (1st Ed.). New York, NY: ERIC.

Engler, D. (1970). Instructional Technology and the Curriculum. The Phi Delta Kappan, 51(7), 379-381. https://www.jstor.org/ stable/20372679

Ertmer, P. A. (1999). Addressing First- and Second-Order Barriers to Change: Strategies for Technology Integration. Educational Technology Research and Development, 47(4), 47-59.

Ertmer, P. A., Ottenbreit-Leftwich, A. T., Sadik, O., \& Sendurur, E. (2012). Teacher beliefs and technology integration practices: A critical relationship. Computers \& Education, 59(2), 423-435.
Fullan, M. (2000). The role of the head in school improvement. England: National College of School Leadership. Retrieved from https://eclass.uoa.gr/modules/document/file.php/ PPP445/06_fullan.pdf

Gustafson, K. (1978). The Future of Instructional Development: Through the Looking Glass Darkly. Journal of Instructional Development, 2(1), 1-5.

Hansen, J. W. (2000). To Change Perceptions of Technology Programs. The Journal of Technology Studies, 17-18. Retrieved from https://scholar.lib.vt.edu/ejournals/JTS/SummerFall-2003/pdf/hansen.pdf

Jhurree, V. (2005). Technology integration in education in developingcountries: Guidelines to policy makers. International Education Journal, 6(4), 467-483. Retrieved from https://files. eric.ed.gov/fulltext/EJ855000.pdf

Jimoyiannis, A., \& Komis, V. (2006 ). Exploring secondary education teachers' attitudes and beliefs towards ICT adoption in education. Themes in Education, 7(2), 181-204.

Kia, M., Shayan, E., \& Ghotb, F. (2000). The importance of information technology in port terminal operations. International Journal of Physical Distribution \& Logistics Management, 30(3/4), 331-344.

Knezek, G., \& Christensen, R. (2008). The Importance of Information Technology Attitudes and Competencies in Primary and Secondary Education. In Springer International Handbook of Information Technology in Primary and Secondary Education (Vol. 20, pp. 321-331). Boston, MA: Springer Science.

Kozma, R. B., \& Vota, W. S. (2014). ICT in Developing Countries: Policies, Implementation, and Impact. In: J. Spector, M. Merrill, J. Elen, and M. Bishop (Eds.), Handbook of Research on Educational Communications and Technology. New York, NY: Springer. https://doi.org/10.1007/978-1-4614-3185-5_72

Levin, T., \& Wadmany, R. (2006). Teachers' Beliefs and Practices inTechnology-based Classrooms:A Developmental View. Journal of Research on Technology in Education, 39(2), 157181.

Marcinkiewicz, H. (1996). Motivation and Teachers' Computer Use. In: Proceedings of Selected Research and Development Presentations at the 1996 National Convention of the Association for Educational Communications and Technology. Indianapolis, IN. https://eric.ed.gov/?id=ED397818

Mikre, F. (2011). The Roles of Information Communication Technologies in EducationReview Article with Emphasis to the Computer and Internet. Ethiopian Journal of Education and Sciences, 6(2), 1-16. Retrieved from https://www.ajol.info/ index.php/ejesc/article/view/73521

Mueller, J., Wood, E., Wiloughby, T., Ross, C., \& Specht, J. (2008). Identifying discrimating variables between teachers who fully integrate computers and teachers with limited integration. Computers and Education, 51, 1521-1526.

Mumtaz, S. (2000). Factors Affecting Teachers' Use of Information and Communications Technology: a review of the literature. 
Nga TRAN, Thanh LE, Lan NGUYEN, Linh HOANG, Thuy NGUYEN /

Journal of Information Technology for Teacher Education, 9(3), 319-342.

Muneer, S. (2020). The Information System Management and Its Infrastructure for Supply Chain Management as Antecedents of Financial Performance. Journal of Asian Finance, Economics and Business, 7(1), 229-238. https://doi.org/10.13106/ jafeb.2020.vol7.no1.229

Nguyen, K. Q., \& Nguyen, C. G. (2008). An African Exploration of the East Asian Education Experience. Washington DC: The World Bank.

Nguyen, X. T., \& Luu, Q. K. (2020). Factors Affecting Adoption of Industry 4.0 by Small- and Medium-Sized Enterprises: A Case in Ho Chi Minh City, Vietnam. Journal of Asian Finance, Economics and Business, 7(6), 255-264. https://doi. org/10.13106/jafeb.2020.vol7.no6.255

Pajares, M. (1992). Teachers' Beliefs and Educational Research: Cleaning up a Messy Construct. American Educational Research Association, 62(3), 307-332.

Rangaswamy, A., \& Gupta, S. (2000). Innovation Adoption And Diffusion In The Digital Environment: Some Research Opportunities. eBusiness Research Center Working Paper 021999. Pennsylvania State University.

Rogers, E. M. (1995). Diffusion of Innovation. New York, NY: The Free Press.
Taylor, P. (2015). The Importance of Information and Communication Technologies (ICTs): An Integration of the Extant Literature on ICT Adoption in Small and Medium Enterprises. International Journal of Economics, Commerce and Management, 3(5), 274-295.

Tschannen-Moran, M., \& Johnson, D. (2010). Exploringn literacy teachers' self- efficacy beliefs: Potententail sources at play. Teaching and Teacher Education: An International Journal of Research and Studies, 27(4), 751-754.

Tschannen-Moran, M., Hoy, A. W., \& Hoy, W. K. (1998). Teacher Efficacy: Its Meaning and Measure. Review of Educational Research, 68(2), 202-248.

Wastiau, P., Blamire, R., Kearney, C., \& Quittre, V. (2013). The Use of ICT in Education: a survey of schools in Europe. European Journal of Education Research, Development and Policy, 48(1), 1-17.

Windschitl, M., \& Sahl, K. (2002). Tracing Teachers'Use of Technology in a Laptop Computer School: The Interplay of Teacher Beliefs,Social Dynamics,and Institutional Culture. American Educational Research Journal, 39(1), 165-205.

Zhao, Y., Pugh, K. J., Sheldon, S. B., \& Byers, J. L. (2002). Teacher Adoption of Technology: A Perceptual Control Theory Perspective. Journal of Technology and Teacher Education, 104(3), 482-515. 